Jurnal Teknologi, 51(F) Dis. 2009: 131-141

(C) Universiti Teknologi Malaysia

\title{
COMPUTER-BASED SAFETY TRAINING FOR SEMICONDUCTOR INDUSTRY
}

\author{
NADIA KAMARRUDIN ${ }^{1}$, MOHAMED WIJAYANUDDIN ALI ${ }^{2}$, \\ MOHD. ZAKI KAMSAH ${ }^{3}$, MIMI HARYANI HASSIM ${ }^{4}$ \& KAMARIZAN KIDAM $^{5}$
}

\begin{abstract}
A computer-based safety training (CBT) for semiconductor industry using web as the platform was developed. The CBT system is called Sistem Latihan Keselamatan Berasaskan Komputer (SLK). The CBT system has two main sections which are safety theory modules and accident prevention scenarios. The survey conducted in semiconductor industry concluded that $86.7 \%$ of the respondents have successfully increased their safety awareness and understanding towards safety at workplace after studying the SLK system. The highest increment is about $46 \%$ and the lowest is about $8 \%$. SLK system was found to be a practical tool in the selected semiconductor industry and has successfully increased the awareness of safety procedures as well as the understanding of good working practices.
\end{abstract}

Keywords: Safety training management system; semiconductor industry; computer-based safety training system; safety perception

\begin{abstract}
Abstrak. Sistem latihan keselamatan berasaskan komputer atau SLK telah dibangunkan bagi industri semikonduktor dengan menggunakan web sebagai platform. Sistem ini mempunyai dua bahagian utama, iaitu modul teori keselamatan dan senario pencegahan kemalangan. Kajian dijalankan di industri semikonduktor mendapati $86.7 \%$ di kalangan responden telah berjaya meningkatkan tahap kesedaran dan kefahaman mereka terhadap aspek keselamatan di tempat kerja setelah mempelajari sistem SLK. Peningkatan tersebut adalah di antara 8\% sehingga 46\%. Kajian ini mendapati sistem SLK merupakan satu kaedah yang praktikal bagi industri semikonduktor yang dikaji dan ia juga telah berjaya meningkatkan tahap kesedaran terhadap prosedur keselamatan serta kefahaman tentang amalan kerja selamat.
\end{abstract}

Kata kunci: Sistem pengurusan latihan keselamatan; industri semikonduktor; sistem latihan keselamatan berdasarkan komputer; persepsi keselamatan

\subsection{INTRODUCTION}

Accident prevention at workplace is one of the major tasks for managers due to its economic, social and legal implications [1]. It is a controlled process which represents an ability to control machine performance, human behaviour and the environment in which the individual is working. It is a controlled process because a procedure must

\footnotetext{
1 Faculty of Chemical Engineering, Universiti Teknologi MARA, 40450 Shah Alam, Selangor, Malaysia

2,3,4\&5 Chemical Engineering Department, Faculty of Chemical and Natural Resources Engineering, Universiti Teknologi Malaysia, 81310 UTM Skudai, Johor, Malaysia

Tel: +06-07-5535892. Email: m.w.ali@fkkksa.utm.my
} 
be identified for the prevention and correction of unsafe acts and condition [2]. Accident prevention is an essential component for the successful and profitable operation of any industry. Losses that results from an accident not only affect the injured worker but the organization and other workers as well [2].

All accidents can be categorized as being caused by either environmental conditions and/or human behaviour [2]. Accident can happen even in the most safety conscious environment [3]. The negative impact of accident is long-term and it may take time for workers to recover from the psychological shock or endure changes to one's life-style after the accident [4]. Accidents at workplace have traditionally been attributed mainly to the unsafe working conditions and also unsafe acts. The following five conditions are contributing factors to the occurrence of accidents [2]:

(1) Lack of knowledge

(2) Poor work habits and attitudes

(3) Unsafe behaviour

(4) Insufficient skill

(5) Environmental hazards.

Effective occupational, safety and health management and its relation with productivity have been considered as an important element when managing the interaction between system and people [5]. Human factors play a significant role in the safety performance of organizations. The unsafe behaviour adopted by human can lead to accidents [5]. Therefore, safety program must be designed to accomplish their purpose in two primary ways: focusing on unsafe employee action and the other on unsafe working conditions [3]. The first approach is a safety program to create a psychological environment and employee attitudes that promote safety. Accident can be reduced when employee consciously and subconsciously think about safety [3]. The second approach to safety program design is to develop and maintain a safe physical environment. Here the environment is altered to prevent accidents [3].

Training is a major endeavour in all-modern professional practices [6]. All accident prevention work, whether or not it is educationally intended, is nevertheless educational in its effect upon the individual employee whom it necessarily involves [7]. This is clearly indicated by evident that well-trained and careful worker may avoid injury on dangerous work and untrained and careless workers may be injured under the safest possible conditions [7]. The safety training is intended to ensure that employees perform their jobs properly, thus promoting safety and increasing productivity. The Department of Occupational, Safety and Health (DOSH) Malaysia has listed several training objectives including [8]:

(1) To groom a qualified, educated, capable and virtuous workforce

(2) To improve skill, efficiency and expertise

(3) To achieve productive and high quality work performance

(4) To improve career development. 
Nowadays, almost all trainings are delivered via CD-ROMs, intranets or the internet rather than the conventional method (formal class, training manual and on-the-job training). Although each learning technology has some unique features, they all use computers in one way or another to deliver the training. Interactive computer programs for training can reduce long-term training costs and training time for learners [9]. They are also flexible and attractive. These systems also have several added strength such as efficient, low cost relative to on-the-job training, supports course management, and more convenience for instructional delivery than lecture [6, 10-12]. Therefore, the computer-based training systems are practical to industry. Furthermore, with these systems, employees will understand more about safety at work place and enhance their safety attitude, knowledge and skill level.

The objectives of this study are:

(1) To study the safety training management system background in the selected semiconductor industry

(2) To develop a computer-based safety training module for a semiconductor industry

(3) To verify the usefulness of the developed system in the selected semiconductor industry.

\subsection{METHODOLOGY}

\subsection{Initial Survey}

The purpose of the survey was to identify the background of the safety training management system including the employer's roles, employees' awareness towards safety at workplace and computer usage in safety training based on employee perceptions. The key findings that emerged from the survey were major requirements for computer-based safety training system development. A survey was conducted in a large multinational manufacturing company at Seremban, Negeri Sembilan.

A survey questionnaire was used to obtain responses on occupational, safety and health issues in the semiconductor industry. In this survey, the questionnaire was divided into two parts. Part 1 was on respondent's background and part 2 was divided into three sub parts, which were the employers' role, employees' safety awareness and computer usage. The questionnaire was pre-tested to find out the time duration to complete the questionnaire, the wording errors, unanswerable questions and also to find out on its suitability for respondents to answer.

An interview was conducted to obtain valid responses and to record the responses accurately and completely, and also to get information on the company's industrial safety training system. Once the data have been collected by the survey, they will be translated into a format appropriate for computer analysis. In this research, the data was analysed using Statistical Package for Social Sciences (SPSS) version 14.0. 


\subsection{Development of Computer-based Safety Training System}

The system has two main sections which are the safety theory modules and accident prevention scenarios. As per discussion with health, safety and environment personnel, three basic safety theory modules were developed including the quiz of every module. The modules are:

(1) Ergonomics

(2) Personal Protective Equipment (PPE)

(3) Material Safety Data Sheet (MSDS)

Trainees will select any module they like and the system will guide them through with the training. Then, they choose whether they want to continue with the quiz or another module. If they choose the quiz module, they must get a minimum score of $90 \%$ before they can proceed to another module. Failing to obtain a score of $90 \%$ will require them to repeat the module and quiz or quit the system.

In the accident prevention part, 14 accident scenarios were developed to test the employees understanding towards safety at workplace. The scenarios are related to the semiconductor industry and safety theory module (ergonomics and personal protective equipment), such as chemical handling, back injuries, musculoskeletal injuries, did not wear the specific PPE and etc. The trainee will be given choices of scenarios and he/she will pick the preferred scenario and analyze it. They will answer several questions based on how to prevent the accident from occurring, causes of the accident, and what action should be taken if the scenario takes place. They must get a minimum score of $90 \%$ to proceed to other scenario or otherwise repeat the module or quit the system.

\subsection{Case Study}

The safety knowledge test was conducted to verify the usefulness and effectiveness of the developed system to the selected semiconductor employees. The employees were tested on their knowledge of the safety procedures and industrial working practices before and after they used the system. The questionnaire is divided into 2 parts which are safety theory and accident scenario. The data was analysed based on the percentages of respondents' score in safety knowledge test before and after they used the system.

\subsection{RESULTS AND DISCUSSION}

\subsection{Initial Survey}

From the initial findings, the respondents agreed that management is very serious about Occupational Safety and Health at workplace. Majority of respondents aware on the importance of safety aspect and fully responsible towards personal safety at 
workplace. Besides that, the respondents generally inclined to agree that they felt more comfortable if safety trainings at workplace are delivered via computer. $78.8 \%$ and $82.1 \%$ of respondents said that computer usage in safety training can increase their understanding towards safety at workplace and reduce long-term training time, respectively. However, $88.2 \%$ of respondents said that they are comfortable with their existing safety training. The key findings emerged from the survey were major requirements for computer-based safety training system development.

\subsection{Computer-based Safety Training System}

SLK was developed using web-based application. The system is divided into two parts, safety theory modules and accident prevention scenarios. The system consists of 3 safety theory modules which are:

(1) Ergonomics

- Ergonomics is commonly thought of as how companies design tasks and work areas to maximize the efficiency and quality of their employees' work. The goal of ergonomics is to make the interaction of humans with machines as smooth as possible, enhancing performance, reducing errors, and increasing user satisfaction through comfort and aesthetics. The main topics are introduction to ergonomics at workplace, ergonomics awareness and quiz. Figure 1 shows the example of ergonomics module.

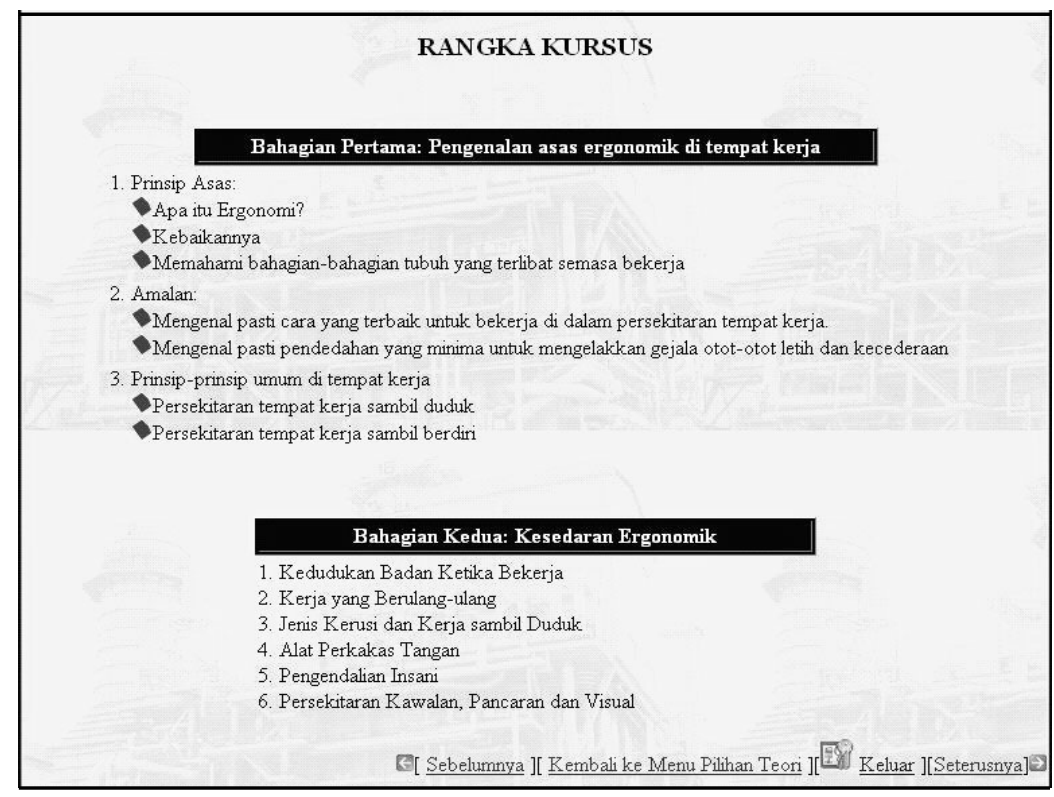

Figure 1 Example of the ergonomics module 
(2) Personal protective equipment

- Personal protective equipment, or PPE, is designed to protect employees from health and safety hazards that cannot be practically removed from their work environment. Figure 2 shows the example of the PPE module. Personal protective equipment is designed to protect many parts of their body including eyes, face, head, hands, feet, respirator system and ears. Personal protective equipment module is divided into 3 parts which are introduction to personal protective equipment, understanding personal protective equipment and quiz.

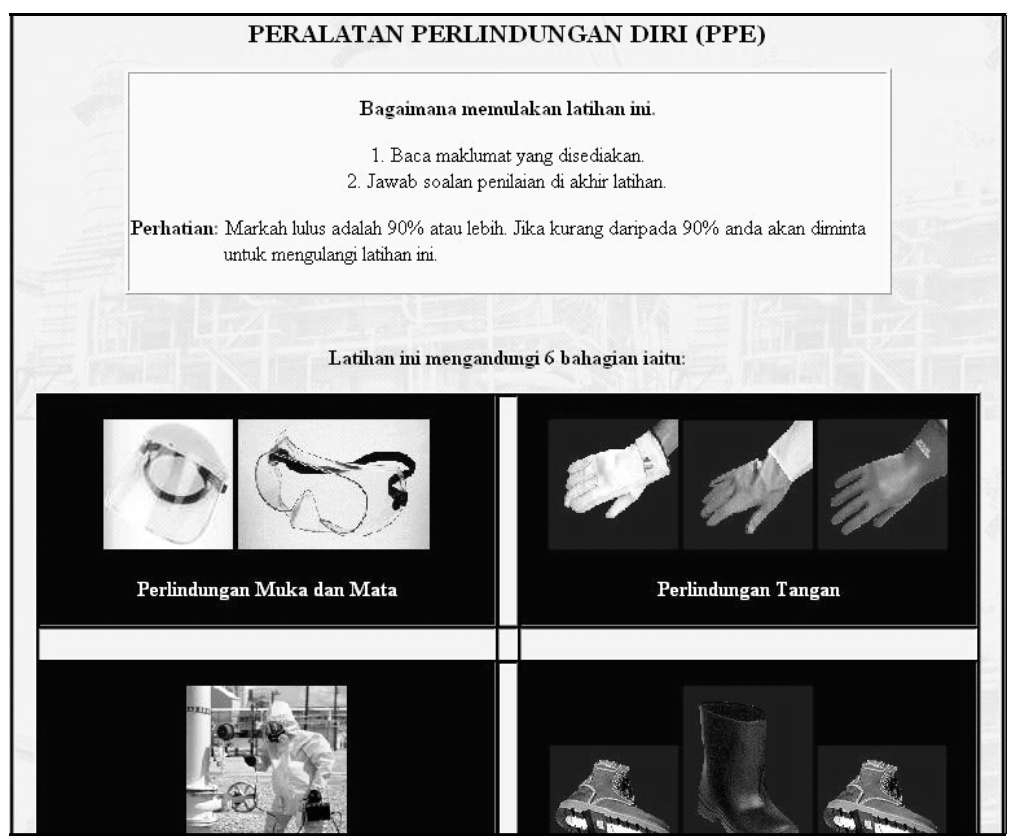

Figure 2 Example of the personal protective equipment (PPE) module

(3) Material safety data sheet

- A material safety data sheet (MSDS) is a form containing data regarding the properties of a particular substance. An important component of product stewardship and workplace safety, it is intended to provide workers and emergency personnel with procedures for handling or working with that substance in a safe manner. The MSDS module is divided into 5 parts which are introduction to MSDS, understanding chemical exposure, understanding MSDS, list of MSDS and quiz. The MSDS information also includes instructions for the safe use and potential hazards associated with a particular material or product. Figure 3 shows the example of the MSDS module. 


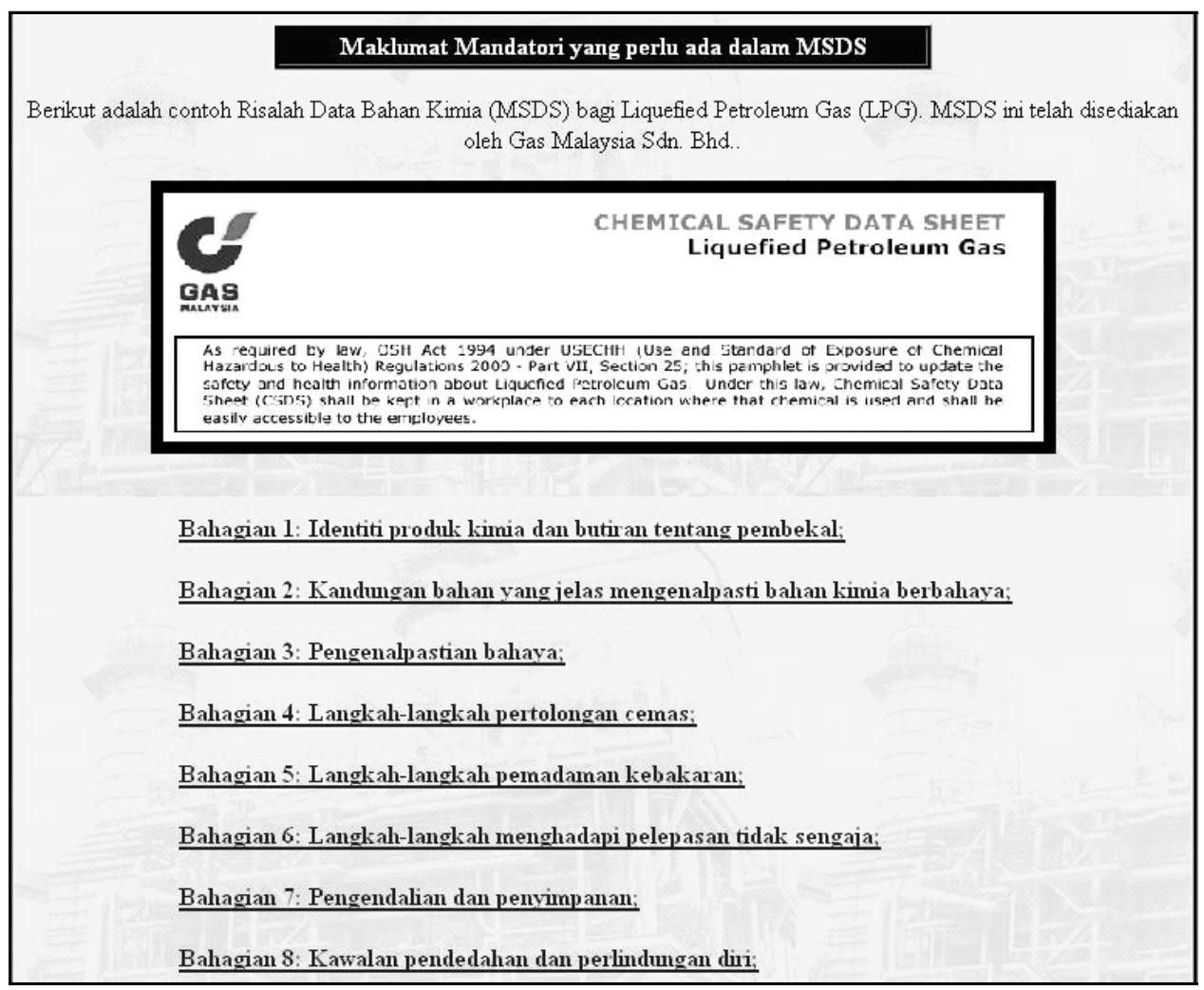

Figure 3 Example of MSDS module

The SLK is more focused to semiconductor industries because there are listed the chemicals used in semiconductor industries in MSDS module and showed the good working practices especially for semiconductor industries in ergonomic module. Quizzes are provided at the end of every section of the module. The user must get a minimum score of $90 \%$ before they can proceed to another module. Failing to obtain a score of $90 \%$ will require them to repeat the same module and quiz or quit the system. If they successfully answered (minimum score of 90\%) the quiz, they can choose either to select another module or view the quiz answers.

In the accident prevention parts, 14 types of accident scenarios were developed as shown in Figure 4 . The scenarios are related to the semiconductor industry and safety theory module (ergonomics and personal protective equipment) such as chemical handling, back injuries, musculoskeletal injuries, not wearing the specific PPE and etc. The test takes about 10 to 20 minutes per scenario to complete.

Figure 5 presents the example of accident scenario page. The analyses must be successful with a minimum score of $90 \%$. Failing to obtain a score of $90 \%$ will require them to repeat it or quit the system. If they successfully answer the scenario quiz, they can choose either to select another scenario or view the scenario quiz answer. 


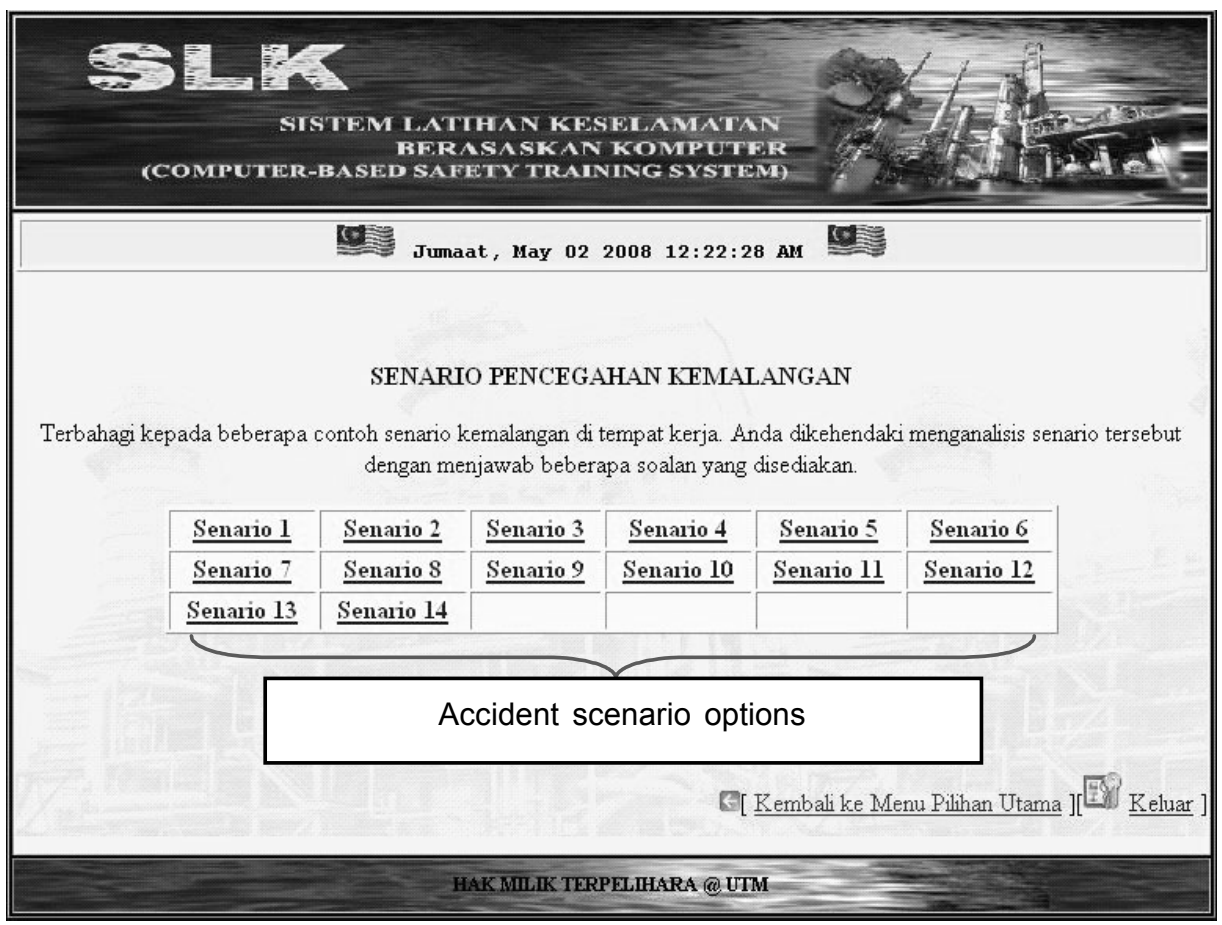

Figure 4 Accident prevention scenarios page

\section{SENARIO 3}

Katakan sekarang anda sedang membaiki mesin yang tersangkut. Untuk menjalankannya semula, anda menyeluk ke bawah penghalang keselamatan dan menarik benda yang tersangkut. Anda melakukannya dengan pantas, tetapi tanpa menutup suis seperti mana yang diarahkan dalam prosedur.

Jawab soalan-soalan berikut. Markah lulus adalah $90 \%$ atau lebih. Jika kurang daripada $90 \%$ anda akan diminta untuk mengulangi latihan ini.

Bolehkah anda tercedera?

Tidak, kerana saya bergerak pantas.

Mungkin.

Ya, kerana tangan saya boleh tersangkut di dalam mesin

Tidak pasti.

Adakah tindakan ini tindakan yang tidak selamat?

Tidak pasti.

O $\mathrm{Ya}$, kerana tindakan ini boleh menyebabkan kemalangan atau kecederaan.

Tidak, tindakan ini tidak menyebabkan kemalangan atau kecederaan.

OMungkin,tindakan ini tidak selamat.

Figure 5 Example of scenario 


\subsection{Safety Knowledge Test}

The safety knowledge test was conducted to verify the usefulness and effectiveness of the developed system to the selected semiconductor employees. The employees were tested on their knowledge of the safety procedures and industrial working practices before and after they used the SLK system. The questionnaire was divided into 2 parts which are safety theory and accident scenario. The test took about 15 to 30 minutes to complete and 30 respondents participated in this test.

Tables 1 and 2 show the result for safety knowledge test. 26 of 30 respondents $(86.7 \%)$ have increased their quiz scores. The highest increment is about $46 \%$ and the lowest is about $8 \%$. This situation showed that the respondents understood better about safety at their workplace after going through the SLK system. This is also means that the module has helped the respondents to enhance their safety attitude, knowledge and skill level. The respondents have managed to apply the theory to the scenario cases.

However, 4 of them (13.3\%) had the same score before and after going through the system. This result showed that he/she might be not pay attention to the information in

Table 1 Results for safety knowledge test

\begin{tabular}{cccc}
\hline $\begin{array}{c}\text { Number of } \\
\text { Respondent }\end{array}$ & $\begin{array}{c}\% \text { Before } \\
\text { Treatment }\end{array}$ & $\begin{array}{c}\% \text { After } \\
\text { Treatment }\end{array}$ & $\begin{array}{c}\% \text { of Increment } \\
\mathbf{1}\end{array}$ \\
$\mathbf{2}$ & $69 \%$ & $92 \%$ & $\mathbf{2 3} \%$ \\
$\mathbf{3}$ & $62 \%$ & $92 \%$ & $\mathbf{3 0} \%$ \\
$\mathbf{4}$ & $77 \%$ & $92 \%$ & $\mathbf{1 5} \%$ \\
$\mathbf{5}$ & $46 \%$ & $92 \%$ & $\mathbf{4 6} \%$ \\
$\mathbf{6}$ & $69 \%$ & $92 \%$ & $\mathbf{2 3} \%$ \\
$\mathbf{7}$ & $85 \%$ & $85 \%$ & $\mathbf{0} \%$ \\
$\mathbf{8}$ & $69 \%$ & $85 \%$ & $\mathbf{1 6} \%$ \\
$\mathbf{9}$ & $69 \%$ & $85 \%$ & $\mathbf{1 6} \%$ \\
$\mathbf{1 0}$ & $62 \%$ & $92 \%$ & $\mathbf{3 0} \%$ \\
$\mathbf{1 1}$ & $87 \%$ & $100 \%$ & $\mathbf{1 3} \%$ \\
$\mathbf{1 2}$ & $60 \%$ & $100 \%$ & $\mathbf{4 0} \%$ \\
$\mathbf{1 3}$ & $75 \%$ & $88 \%$ & $\mathbf{1 3} \%$ \\
$\mathbf{1 4}$ & $50 \%$ & $88 \%$ & $\mathbf{3 8} \%$ \\
$\mathbf{1 5}$ & $60 \%$ & $100 \%$ & $\mathbf{4 0} \%$ \\
$\mathbf{1 6}$ & $85 \%$ & $85 \%$ & $\mathbf{0} \%$ \\
$\mathbf{1 7}$ & $75 \%$ & $88 \%$ & $\mathbf{1 3} \%$ \\
$\mathbf{1 8}$ & $87 \%$ & $100 \%$ & $\mathbf{1 3} \%$ \\
$\mathbf{1 9}$ & $80 \%$ & $80 \%$ & $\mathbf{0} \%$ \\
$\mathbf{2 0}$ & $92 \%$ & $100 \%$ & $\mathbf{8} \%$ \\
$\mathbf{2 1}$ & $63 \%$ & $88 \%$ & $\mathbf{2 5} \%$ \\
$\mathbf{2 2}$ & $77 \%$ & $92 \%$ & $\mathbf{1 5} \%$ \\
$\mathbf{2 3}$ & $75 \%$ & $75 \%$ & $\mathbf{1 2} \%$ \\
\hline
\end{tabular}


140 NADIA, MOHAMED WIJAYANUDDIN, MOHD. ZAKI, MIMI HARYANI \& KAMARIZAN

Table 2 (Continued)

\begin{tabular}{cccc}
\hline $\begin{array}{c}\text { Number of } \\
\text { Respondent }\end{array}$ & $\begin{array}{c}\% \text { Before } \\
\text { Treatment }\end{array}$ & $\begin{array}{c}\% \text { After } \\
\text { Treatment }\end{array}$ & $\%$ of Increment \\
\hline $\mathbf{2 4}$ & $54 \%$ & $69 \%$ & $\mathbf{1 5} \%$ \\
$\mathbf{2 5}$ & $63 \%$ & $88 \%$ & $\mathbf{2 5} \%$ \\
$\mathbf{2 6}$ & $46 \%$ & $92 \%$ & $\mathbf{4 6} \%$ \\
$\mathbf{2 7}$ & $60 \%$ & $80 \%$ & $\mathbf{2 0} \%$ \\
$\mathbf{2 8}$ & $69 \%$ & $92 \%$ & $\mathbf{2 3} \%$ \\
$\mathbf{2 9}$ & $75 \%$ & $88 \%$ & $\mathbf{1 3} \%$ \\
$\mathbf{3 0}$ & $40 \%$ & $80 \%$ & $\mathbf{4 0} \%$ \\
& Average & & $\mathbf{2 0} \%$ \\
\hline
\end{tabular}

safety module and just ticked the same answer for both test. Besides that, the possibility to get the same and lower score after going through the SLK system is very low if they did this safety knowledge test very well. It was proven by the majority $(86.7 \%)$ of the respondents who increased their test score after going through the system. The total average of the increment is about $20 \%$.

In conclusion, the findings showed that the SLK system has successfully helped to increase the awareness of safety procedures as well as the understanding of good working practices among selected semiconductor employees.

\subsection{CONCLUSIONS AND RECOMMENDATIONS}

In conclusion, computer-based safety training system such as SLK system is a practical tool for the selected semiconductor industry and has successfully increased the awareness of the safety procedures as well as helping the employees to have a good working practices. It is proven by the result of safety knowledge test. $86.7 \%$ of the respondents have successfully increased their safety awareness and understanding towards safety at workplace after going through the SLK system. The highest increment is about $46 \%$ and the lowest is about $8 \%$.

Furthermore, it enhances the employees' safety attitude, knowledge and skill level and finally, will reduce or minimize the accident or incident at workplace which consequently reduce the compensation costs and accidental losses.

For future work, the following suggestions can be considered in extending and improving the research ability:

(1) Repeating the evaluation survey with a larger sample and a longer time such as 6 month to 1 year in semiconductor industry field or other industry field. This is required to give more feedback to the SLK system.

(2) Improvement of SLK system - The SLK system should be upgraded to offer upto-date knowledge on safety and health culture at workplace. Adding more safety 
theory modules, quizzes and accident scenarios and make up the system to be more attractive and interesting.

(3) Improve the SLK system with two or more languages. This is required to give the opportunity to all of races in Malaysia to use the system. Now, the SLK system only uses Bahasa Malaysia as the interaction language with user.

(4) More media in SLK system - Adding video, audio and animation to make the system to be more attractive and enjoyable.

\section{ACKNOWLEDGEMENT}

This research was supported by Universiti Teknologi Malaysia-Pembangunan Teknologi Perindustrian (UTM-PTP) scholarship.

\section{REFERENCES}

[1] Ismail, Z. and A. Omar. 2003. Employees' Compliance with OSH Rules and Regulations: An Exploratory Study in Manufacturing and Construction Firms. Proceedings of the National Occupational Safety and Health Conference on Promoting Excellent OSH Culture: A Source for Competitive Advantage. April 21-23. UUM: School of Management. 1-15.

[2] Strong, M. E. 1975. Accident Prevention Manual for Training Programs. United States of America: American Technical Society.

[3] Hin, C. W. 2003. Application of the Total Quality Management Principles in the Training and Educating of Occupational Safety and Health for Employees. Proceedings of the National Occupational Safety and Health Conference on Promoting Excellent OSH Culture: A Source for Competitive Advantage. April 21-23. UUM: School of Management. 105-110.

[4] Tan, H. S. 2003. Emergency Responses Planning in OSH Culture. Proceedings of the National Occupational Safety and Health Conference on Promoting Excel lent OSH Culture: A Source for Competitive Advantage. April 21-23. UUM: School of Management, UUM. 177-183.

[5] Ali, H., N. A. Chew Abdullah and C. Subramaniam. 2003. Embracing Safety Culture to Enhance Organizational Safety Performance. Proceedings of the National Occupational Safety and Health Conference on Promoting Excellent OSH Culture: A Source for Competitive Advantage. April 21-23. UUM: School of Management, UUM. 256-260.

[6] Farias, A. and N. Arvanitis. 1997. Building Software Agents for Training Systems: A Case Study on Radiotherapy Treatment Planning. Journal of Knowledge-based System. 10: 161-168.

[7] Heinrich, H. W., D. Petersen and N. Roos 1980. Industrial Accident Prevention: A Safety Management Approach. United States of America, McGraw-Hill, Inc.

[8] DOSH, Annual Report 2003, http://www.dosh.mohr.gov.my, 2003, [Assessed December 2005]

[9] Kraiger, K. 2002. Creating, Implementing and Managing Effectiveness Training and Development. San Francisco: Jossey-Bass.

[10] Ramachandran, P. and V.Zaloon. 1996. A Computer-based Training System for Process Safety Management. Journal of Computer in Education. 31(1/2): 511-513.

[11] Saoud, E. A. B. 1996. Expert Systems for Management Training in the Construction Industry. University of Edinburgh. PhD Thesis.

[12] Stone, R. 2001. Virtual Reality for Interactive Training: An Industrial Practitioner's Viewpoint. Journal of Human-Computer Studies. 55: 699-711. 